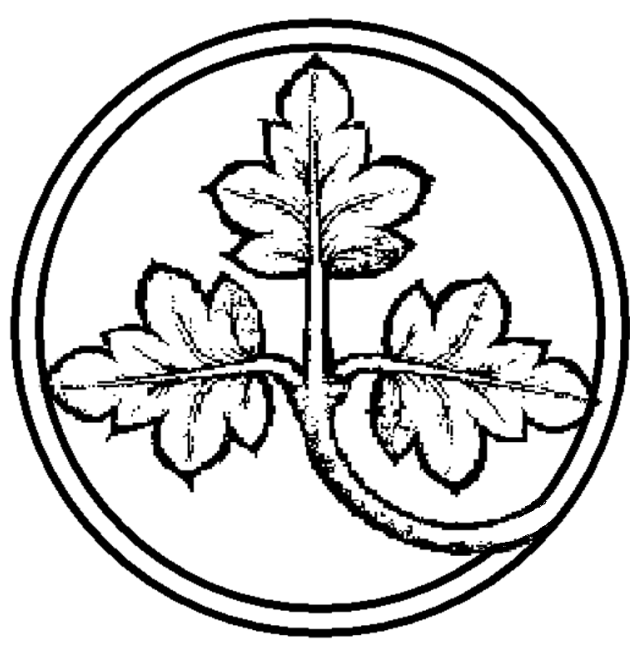

\author{
Preprints of the \\ Max Planck Institute \\ for Research on Collective Goods \\ Bonn \\ 2004/7
}

Governance in International Trade:

Judicialisation and Positive Integration in the WTO

Dirk De Bièvre 


\section{Governance in International Trade: Judicialisation and Positive Integration in the WTO}

Dirk De Bièvre

July 2004 


\section{Dirk De Bièvre ${ }^{1}$ \\ Governance in International Trade: Judicialisation and Positive Integration in the WTO}

\section{Summary}

Positive integration among states, defined as the correction of negative externalities from liberalisation, is generally assumed to be very difficult to achieve on the European level, let alone on the international or global level. The political transaction costs of achieving positive integration legislation indeed seem daunting in an organisation such as the World Trade Organization (WTO), which operates under conditions of unanimity and has a membership of over 140 sovereign states. Yet, member states seem to have crossed the Rubicon: They have concluded a number of agreements that impose positive obligations to adopt new policy measures in fields traditionally restricted to the sovereign nation-state. There has been consistent political pressure to graft other, non-trade issues onto the WTO framework, i.e. to enlarge an organisation that formerly dealt exclusively with trade into a governance structure that also has regulatory competences in other areas of public policy. WTO member states have indeed introduced the obligation to protect intellectual property rights internationally, and they have concluded agreements on health, on technical barriers to trade, and on investment - each of these being fields of public policy for which more specialised agencies within the United Nations system would seem to have been the more natural locus for such agreements. Further, there have been - hitherto unsuccessful - calls to bring labour rights, environmental standards, or competition policy under the jurisdiction of the WTO.

This raises the question: why and under which conditions is positive integration possible in the WTO? The present paper seeks to formulate theoretically embedded hypotheses that answer this question. I argue that judicialisation - the presence of binding third party enforcement - makes every single WTO commitment more credible. Because judicialisation facilitates enforcement, it exerts force on political actors in the legislative arm of the organisation to bring positive integration issues under the jurisdiction of the WTO. The aim of this paper is to explore the explanatory force of this general hypothesis in empirical cases of positive integration (intellectual property, health, technical barriers to trade, and investment) and to come to new theoretical and empirical insights about the sources of and conditions for international cooperation. This paper thus aims to

Post-doctoral Research Fellow at the Mannheimer Zentrum für Europäische Sozialforschung (MZES), Universität Mannheim (Dirk.DeBievre@mzes.uni-mannheim.de). I would like to thank Stefano Bartolini, Daniele Caramani, Chad Damro, Andreas Dür, Christoph Engel, Edgar Grande, Adrienne Héritier, Beate Kohler-Koch, Alkuin Kölliker, Petros Mavroidis, Wolfgang Streeck, and Michael Zürn, as well as an anonymous referee from the VolkswagenStiftung, for previous discussions and comments on the subject of this paper; and finally, I thank Darrell Arnold for painstakingly correcting my English. All remaining inconsistencies are mine. I gratefully acknowledge research funding from the Max-Planck-Institut zur Erforschung von Gemeinschaftsgütern in Bonn and the European Research and Training Network "Dynamics and Obstacles to European Governance” at the MZES in Mannheim (contract number HPRN-CT-2002-00233). The present research project was approved for future funding by the VolkswagenStiftung, Schwerpunkt "Globale Strukturen und deren Steuerung”. 
contribute to interdisciplinary research on judicialisation in international trade governance and the impact of judicialisation on the emergence of global governing structures.

\section{Kurzfassung}

Eine Politik der positiven Integration, definiert als Politik, die die negativen Folgen von Marktintegration korrigiert, stellt schon auf europäischer Ebene eine Herausforderung für die zwischenstaatliche Koordination dar. Noch schwieriger gestaltet sie sich auf internationaler und globaler Ebene. Die politischen Transaktionskosten, die entstehen, wenn mehr als 140 Staaten in einem Einstimmigkeit erfordernden, legislativen Prozess - wie in der Welthandelsorganisation (WHO) Schritte in Richtung einer Politik der positiven Integration unternehmen, sind sehr hoch. Dennoch haben in Fall der WHO die Mitgliedstaaten den Rubikon überschritten und eine Anzahl von Übereinkommen getroffen, die die Mitgliedstaaten dazu verpflichten, bestimmte politische Massnahmen in Bereichen zu treffen, die früher ausschliesslich den Nationalstaaten oblagen. Es besteht ein ständiger politischer Druck, den Rahmen der WHO um Elemente zu ergänzen, die keinen exklusiven Handelscharakter haben, und damit die zuvor auf reine Handelsfragen beschränkte Organisation zu einer Steuerungsstruktur mit regulativen Aufgaben umzugestalten. So wurden Schritte zur internationalen Regulierung des geistigen Eigentums eingeleitet, sowie Abkommen über Gesundheit, technische Handelshemmnisse und Investitionen abgeschlossen. Da die Sonderorganisationen der Vereinten Nationen jedoch bereits Kompetenzen in diesen Politikbereichen besaßen, wäre zu erwarten gewesen, dass sie den institutionellen Kontext zur Behandlung der jeweiligen Regelungen und Abkommen bilden würden. Weiter gibt es - bisher allerdings erfolglose - Bestrebungen weitere Politikbereiche wie etwa das Arbeitsrecht, die Umweltpolitik oder die Wettbewerbspolitik unter der Zuständigkeit der WHO zu bringen.

Das wirft die Frage auf: warum und unter welchen Bedingungen ist eine Politik der positiven Integration in der WHO möglich? Dieses Papier formuliert theoretisch eingebettete Hypothesen, die versuchen, diese - bisher unbeantwortete - Frage zu beantworten. Ich argumentiere, dass Juridifizierung $^{2}$, d.h. die Existenz einer verbindlichen Konfliktschlichtung durch Dritte, jeder einzelnen Verpflichtung der Welthandelsorganisation mehr Glaubwürdigkeit verleiht. Indem die Juridifizierung die Durchsetzung der Bestimmungen der WHO erleichtert, setzt sie Anreize für die politischen Akteuren in der legislativen Arena der WHO, Fragen der positiven Integration in den Zuständigkeitsbereich der Gerichtsbarkeit der WHO zu bringen. Es ist das Ziel des Papiers, die Erklärungskraft dieser Hypothese zu untersuchen, anhand der empirischen Beispiele positiver Integration in der WHO (geistiges Eigentum, Gesundheit, technische Handelsbarrieren und Investitionsbarrieren) zu erkunden, und neue theoretische und empirische Einsichten in die Ursachen und Bedingungen einer internationalen Zusammenarbeit zu gewinnen. Damit soll ein Beitrag zu einer interdisziplinären Debatte über die Juridifizierung des Welthandelsregimes und deren Einfluss auf die Entstehung globaler Regierungsformen geleistet werden.

2 Der Begriff der 'Juridifizierung' zielt auf die Anwesenheit eines schlichtenden Dritten ab, wogegen mit dem Begriff der 'Verrechtlichung' eher die Schaffung neuer Regeln durch die Vertragspartner gemeint ist. 


\section{Table of Contents}

1. Research question: Why positive integration in the WTO?................................................ 4

2. Preliminary answers: Hypotheses linking judicialisation and positive integration .................. 5

3. Theory embeddedness: State of the art, enduring riddles, and alternative hypotheses............. 7

3.1. International institutions and domestic trade politics .................................................. 7

3.2. Judicialisation: Differences with the European experience …........................................... 8

3.3. Whence the demand for positive integration?........................................................... 10

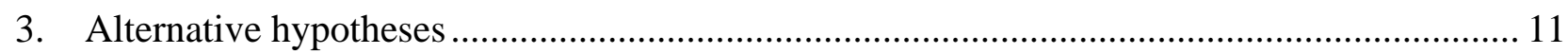

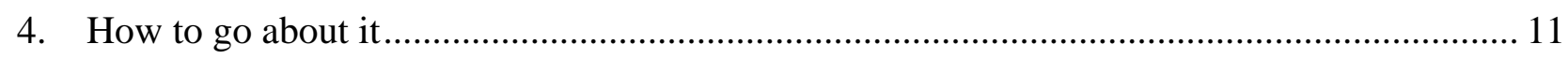

4.1. Specifying dependent and independent variables ......................................................... 11

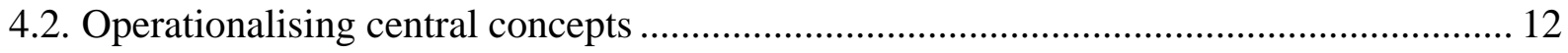

4.3. Case selection: hypothesis testing and hypothesis generation ....................................... 13

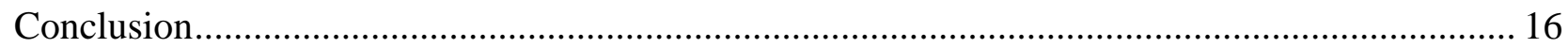

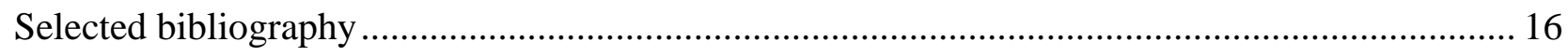




\section{Research question: Why positive integration in the WTO?}

International trade governance is decisively and prudently moving towards positive integration. At the end of the Uruguay Round, member states of the World Trade Organization included a set of agreements that introduced positive obligations to adopt new domestic policy measures (WTO 1995; Trebilcock \& Howse 1999; Hoekman \& Kostecki 2001). Cooperation on trade has thus moved beyond the traditional realm of negative integration, which consists of prohibitions of certain trade restricting measures. The GATT 1947 agreements consisted exclusively of such eliminations of or reductions to barriers to trade in the form of reciprocal tariff concessions. Positive integration agreements, by contrast, contain obligations to adopt certain policy measures aimed at correcting negative externalities due to liberalisation or creating new markets (Scharpf 1996 \& 1999). This form of market integration therefore introduces regulation in areas of public policy traditionally restricted to the sovereign nation-state, and it often requires the reform of domestic institutional arrangements. Under conditions of unanimity, however, positive integration is far more difficult to achieve than negative integration. Negative integration in the GATT/WTO indeed proceeds via the removal of trade barriers in bilateral deals, reciprocal concessions that are then applied in a non-discriminatory way to all other member states. ${ }^{3}$ The bargaining method is therefore not constrained by the decision rule of unanimity, since no member is under an explicit obligation to lower tariffs. Positive integration agreements, by contrast, can only be achieved with the formal approval of all WTO member states.

If positive integration is so difficult to achieve institutionally, the introduction of such agreements into the WTO regulatory framework provokes the following questions: Why and under which conditions is positive integration in the WTO possible? And how deep do these agreements cut into the autonomous regulatory capacity of the sovereign nation-state, i.e. what is their policy impact?

So far WTO agreements that call for positive integration have been concluded regarding issues such as intellectual property protection, health regulation, technical standards, and investment rules. Moreover, there has been consistent political pressure to graft other, non-trade issues onto the WTO institutional framework, i.e. to enlarge a former organisation that dealt exclusively with trade into a governance structure that also has regulatory competences in other areas of public policy, such as labour rights, environmental standards, or competition policy. The general question posed above can therefore be reformulated as a set of more particular, i.e. case-specific, questions. Why have agreements in each of the aforementioned four policy areas been reached and what is their impact? Concurrently, why have other regulatory issues like labour, environment, or competition not been integrated into the WTO legal framework, despite rife political calls for them to be included? The present paper proposes a theoretical explanation for the first question and briefly sketches out paths towards a generalisable explanation for the second.

3 This equality of treatment is usually called most-favoured nation (MFN) treatment, and it is the general provision that makes negative integration powerful in the GATT and the WTO. 


\section{Preliminary answers: Hypotheses linking judicialisation and positive integration}

The move towards positive integration in the WTO can be explained by two factors. First, the judicialisation of the international trading regime, together with multilaterally authorised retaliation, has increased the credibility of rules that fall under WTO jurisdiction. Second, demand for international cooperation on trade in advanced industrialised countries has shifted from tariff reductions to regulation. Such agreements face greater enforcement problems, which can be overcome if these are subject to judicial enforcement. Judicialisation thus exerts a powerful pulling power over political actors to include non-trade regulation, i.e. positive integration, in the WTO regulatory framework.

(1) Judicialisation in the WTO consists in the presence of fully-fledged binding third party enforcement as introduced by the WTO Dispute Settlement Understanding (WTO DSU), backed up with the possibility of multilaterally authorised retaliation in cases of noncompliance. This institutional characteristic of the current trading regime is the result of the reform of the traditional pragmatic, diplomatic, and power bargaining method for resolving trade disputes under GATT 1947. Judicialisation ${ }^{4}$ has made every single WTO commitment more credible - both those regarding the liberalisation commitments (negative integration) and regarding the obligations to proceed with domestic reform (positive integration). The judicial review system of independent panels and possible Appellate Body rulings has greatly increased the transparency of domestic trade regulation and considerably raised the reputation costs attached to non-compliance. Moreover, multilaterally authorised retaliation - as opposed to unilateral action - has given greater force to the option of punishing persistent offenders. As a result, moves towards positive integration tend to gravitate around the WTO, rather than around relevant specialised UN agencies, as political actors supportive of effective international governance in a given policy field seek to bring new and non-trade concerns under the jurisdiction of the WTO judicial arm.

(2) In recent decades, the demand for international cooperation in advanced industrialised countries has shifted from the reduction of tariffs to regulation. Given their large internal markets, large members now have less to gain from mere liberalisation (Garrett 2000). Hence they tend to focus more on positive integration regulation than on negative integration. Regulation in the form of positive integration in the above-mentioned areas poses far greater enforcement problems than simple reciprocal tariff concessions do. Such concessions are largely selfenforcing, since non-compliance can be reciprocated by the withdrawal of concessions (Howse \& Nicolaïdis 2003). Positive integration agreements, on the other hand, do not allow countries to pull out of the agreement by employing a simple tit-for-tat strategy. This is because they contain domestic market-rearrangements and institutional reforms that are costly to undo. Effective multilateral judicial enforcement therefore constitutes a conditio sine qua non, required in order for positive integration agreements to come into existence and to become 
effective. (Yet, it is obviously not the only condition.) In contrast to the demands from advanced industrialised GATT/WTO members, the primary concern in developing countries is negative integration. These members, who make up the large majority of the WTO membership, are interested in market access and tariff liberalisation, especially since the opportunity costs of closure have dramatically increased (Garrett 2001). As a result, the basic method for package deals in international trade rounds now consists of an exchange of concessions on trade-only issues for non-trade regulation. Positive integration agreements are thus a constituent part of overall 'balanced' package deals.

1. Judicialisation in the WTO, combined as it is with possible retaliation, facilitates the enforcement of previous agreements.

2. Strengthened enforcement makes commitments more credible.

3. Strong enforcement exerts a pulling power over political actors in the legislative arm of the organisation to bring positive integration issues that they are supportive of under the jurisdiction of the WTO.

Table 1: Why positive integration in the WTO? Three steps in the causal argument.

\section{Some further implications}

The implication of the hypothesis is that adversaries of positive integration in a particular field of policy will try to prevent any such agreements from coming about under the jurisdiction of the WTO, and will either prefer the continuation of international cooperation in other, already existing international organisations with weak enforcement mechanisms, or the establishment of a new organization, without extensive enforcement powers, similar to the powers in the WTO.

Positive integration and judicialisation are consequently intricately linked phenomena, and they produce interactive effects. Taken together, they give rise to new international political conflicts, not only of a distributional nature, but also of a regulatory nature (Lowi 1964). Political actors as diverse in aim and group composition as intellectual property rights holders, health regulators, standardisation organisations, competition authorities, researchers in the field of genetically modified organisms, advocates for labour rights, environmentalists, and numerous others have now become politically vocal, not only within their traditional areas of political activity, but within the trading system of the WTO as well. New cleavage structures in the political process of trade policy-making are emerging. New actors are trying to enhance their influence on trade policy and exercise their rights under the already existing positive integration agreements, or to exert political pressure on the negotiation and the legislative arm of the WTO to graft other non-trade issues onto the WTO institutional framework. In order to avoid a political backlash against its emerging body of jurisprudence in international economic law, the need to adjudicate on non-trade issues has also induced the judicial arm of the organisation to issue-prudent and nuanced rulings (Ehlermann 2002). The presence of strong judicial institutions exposes the blatant absence of strong political 
institutions that would be able to endow the new rules governing globalisation in trade matters with legitimacy. This has thus given rise to exhortatory calls for the political, legislative arm to make more efficient procedures for rule-making in the WTO (Bogdandy 2001, De Bièvre 2002).

Demands have been formulated to make existing core labour standards enforceable by subjecting them to the jurisdiction of the WTO, a move that would allow for retaliatory tariffs against countries not abiding by international law on child labour or minimum social rights. Other political actors have argued that it would be desirable to integrate international environmental law into the WTO legal framework, subjecting environmental rules to the strictures of the dispute settlement procedure and its Damocles sword of retaliation in cases of non-compliance. Others have called for common standards regarding how domestic competition policy should be conducted. Irrespective of the desirability of such reform plans, an in-depth understanding of the implications of the already existing positive integration agreements might illuminate both academics and practitioners about the possibilities and limits of such a future legal 'constitutionalisation' - however disputed the appropriateness of the term may be - or the emergence of global governance through the World Trade Organization (Charnovitz 2002).

The remainder of this paper is structured as follows. Section 3 presents the state of the art on international trade governance. Section 4 then provides the flesh and bones to the theoretical argument by further defining the central concepts, discussing how they are measured, and the cases to which we would expect the theoretical argument to apply.

\section{Theory embeddedness: State of the art, enduring riddles, and alternative hypotheses}

\subsection{International institutions and domestic trade politics}

Students of the international trading regime have recently observed that the club model of multilateral cooperation has come under fire (Keohane \& Nye 2001). The post-war compromise of 'embedded liberalism' (Ruggie 1982) indeed relied on a set of relatively independent international institutions, composed of clubs of executive negotiators, specialised in their issue area and working virtually in 'splendid isolation' from other areas of public policy. Under such conditions, questions of legitimacy, in terms of accountability and effectiveness, remained restricted to this inner circle of negotiators. This fact, however, does not imply that negative integration under the GATT trading regime produced no significant domestic effects. The delegation of trade competences to the executive and reciprocity in trade agreements so characteristic of the GATT era have indeed been shown to have distinct effects on the collective action of domestic industries (Gilligan 1997; De Bièvre 2003; De Bièvre \& Dür 2004). This logic of pressure politics in trade policy stands in stark contrast to the high degree of ideological and party political mobilisation in the preGATT era. During the first wave of globalisation in the second half of the $19^{\text {th }}$ century, trade policy tended to polarise opinions and interests around cleavage lines of class, opposing agrarians, capitalists, and workers (Rogowski 1989). In a world without international trade institutions, the 
relatively unrestricted movement of capital, labour, and goods could produce its unfettered effects in the political realm, making the trade policy issue a politically highly salient one. Under such conditions, political coalitions were constituted of alliances of different sorts between the representatives of the three factors of production - land, capital and labour. The delegation of trade policy powers and the multilateral use of reciprocity in trade agreements under GATT changed this constellation and gradually fed the domestic demand for further liberalisation, especially of intra-industry trade.

A second feature of the trade policy-making during the GATT regime gradually changed the incentive structure for domestic actors, and consequently the national trade policy process at large. States increasingly relied on 'judicial' trade policy instruments, which further delegated the dayto-day administration of trade policy to the executive. These instruments treat contentious issues and special interest demands in a case-by-case fashion. The most prominent examples include trade policy instruments such as anti-dumping measures, market access investigations, or international trade dispute settlement. ${ }^{5}$ Since they de-link issues, judicial trade policy instruments lead to collective action at the branch levels of particular industrial sectors. Intra-sectoral rather than sector-wide trade associations have consequently ascended, leading to a further fragmentation of the domestic trade policy process (De Bièvre 2003).

Positive integration and the 'new' issues in the international trade regime, however, would seem to counterbalance this type of fragmentation in the trade policy process. Epitomised by the vocal protests at the Seattle meeting, where the $9^{\text {th }}$ multilateral round of trade negotiations was prevented from being launched, trade policy is no longer the realm of exporters, import-competing industries, their intra-sectoral component parts, and executive negotiators. New political actors have successfully gained the centre stage: international property right holders, providers of professional services, health authorities, standardisation organisations, and investors. Others are calling for mechanisms to ensure the provision of public goods other than an open trading system such as environmental protection, core labour standards, or competition rules limiting global cartel practices. What is more, such political actors call for this to be achieved through the institutional capacities of the World Trade Organization in Geneva. Conjectures about the causes for the emergence of such new political actors on the stage of international trade politics therefore merit systematic analysis.

\subsection{Judicialisation: Differences with the European experience}

The first part of the explanatory hypothesis relies on the concept of judicialisation, sometimes also refered to as 'legalization' in the literature. ${ }^{6}$ The judicialisation of international relations has been

5 The category 'judicial trade instruments' is of a more generic nature than the economic, a-institutional, and somewhat misleading term 'non-tariff barriers'. Most judicial instruments such as anti-dumping and countervailing duties are prominent tariff barriers. In essence, they consist of a tariff hike or the threat thereof. For definitions of the aforementioned trade policy instruments, see Goode 1998.

6 I will use the term 'judicialisation' rather than 'legalization'. Semantically, 'legalization' is the process of making legal, as in the phrase 'the legalization of soft drugs', and would therefore seem to be appropriate for 
one of the most significant recent developments in international relations (Keohane, Moravcsik and Slaughter 2000; Stone 1999). ${ }^{7}$ There has indeed been an increasing reliance on quasi-judicial solutions to international conflicts and on the enforcement of binding sets of objectives, rather than on traditional diplomatic channels. Although the direct aim of the present paper is not to investigate the origins of judicialisation, for present purposes the emergence of judicialisation towards the end of the GATT era can be seen as a reaction to the effects of negative integration on behind-the-border issues, which impinge on pre-existing positive integration arrangements on the national or international level.

Two types of international third-party dispute resolution can be distinguished: interstate and transnational. Interstate or international dispute settlement is the reserve of states seeking to enhance compliance with rules previously agreed upon in international treaties, such as in the WTO dispute settlement system (WTO 1995; Palmeter \& Mavroidis 1999). Transnational dispute resolution, on the other hand, allows individuals and nongovernmental entities access, and it has the potential to give rise to significant new constituencies. A comparison with the European experience is particularly enlightening in this respect. First, the WTO secretariat has no powers anywhere close to those of the European Commission to independently initiate court procedures against an individual member state. Enforcement in the WTO is decentralised: only member states can file complaints against non-complying trading partners. Second, the strategic position of the European Court of Justice (ECJ) differs from the position of the WTO panels and the Appellate Body. The ECJ has indeed been credited with keeping integration going while the political institutions of the European Communities approached a deadlock in the 1970s. The doctrine of direct effect and the even more powerful proclamation of the supremacy of European law over national law has proven to have constituted a 'quiet revolution' (Weiler 1994). The GATT dispute settlement system had existed from the outset in 1947, but through veto powers in the beginning and at the end of the proceedings, it remained exclusively in the hands of the affected parties until the late 1980s, thus violating the judicial procedural principle that no person can judge a case in which he or she is party. During the Uruguay Round, GATT contracting parties eliminated these veto points, which had stalled the judicial procedures (GATT 1990). The introduction of binding third-party dispute settlement at the WTO created the expectation that a gradual expansion of the courts jurisdiction would slowly develop (Stone \& Brunell 1998; Stone 1999). WTO panels and the Appellate Body, however, cannot rely on allies in domestic national courts like the ECJ was able to when strategically using preliminary references (Alter 1998; Burley \& Mattli 1993). As a result, in order to avoid risking a backlash against the courts' very powers, the WTO panels and especially the Appellate Body have been remarkably prudent and reconciliatory (Ehlermann 2002). The potential for constructinginternational governance through an autonomous judicial system is therefore much greater if there is cooperation with domestic courts (Mavroidis et al. 1998). At the same time, the very creation of the Appellate Body, a World Trade court in all but name, has de facto taken the interpretation of all WTO agreements out of the hands of the WTO General Council or the Mini-

the legislative process of law-making. The term 'judicial' and its derivations allow a distinction between the legislative and the judicial arm of international organisations. 
sterial Conference, which are de jure competent to interpret, provided they reach a consensus, making any overruling of the Appellate Body ruling practically unthinkable (Weiler 2000). This feature of the judicial procedure has delegated to the appeal judges the task of applying the principle of normative coherence to the body of WTO law. To be fair, this observation does not aim to settle the question whether precedent WTO law is a form of common law crucially dependent on precedent, for that is entirely different matter.

The strictly interstate, as opposed to transnational, mode of dispute settlement has further consequences for the force that judicialisation exerts upon political actors, which differs among different WTO member states. It is more difficult for small, developing countries to make strategic use of the dispute settlement mechanism to enhance their access to foreign markets, and they attract less foreign complaints for a number of reasons (Mavroidis \& Hoekman 1999; Mavroidis, Nordstrom \& Horn 1999; De Bièvre 2002). First and foremost, they lack the market power to credibly threaten to impose retaliatory tariffs. The crippling domestic effects of these would outweigh the benefits of the pressure they might exert on the non-compliant country. Second, these states lack the administrative capacity needed to launch a full-fledged legal complaint against a trading partner that flouts its WTO obligations. And third, developing countries often lack the trade association structure needed to generate information about trade barriers and non-compliance. The hypothesised dynamic effect of WTO judicialisation on negotiation behaviour should therefore be readily observable for large, advanced industrialised WTO members, and far less so for small, developing countries.

It has to be noted that one particular WTO positive integration agreement introduces the obligation to create domestic courts that can enforce the rights conferred by the treaty. The WTO agreement on intellectual property requires the installation of domestic institutions to ensure the rights of intellectual property rights holders, de facto providing protection to foreign property rights holders in developing countries (WTO 1995; Govaere \& Demaret 2001; Abbott \& Gerber 1997). In the event of non-implementation, foreign intellectual property rights holders, however, cannot invoke the WTO agreement in these domestic courts, but are dependent on their own government bringing an interstate complaint to the WTO.

\subsection{Whence the demand for positive integration?}

The second hypothesis relies on the assumption that advanced, industrialised countries will demand regulation and positive integration agreements rather than market-opening, negative integration agreements. Large members indeed have less to gain from liberalisation. The percentage of their GDP created in export and import activities is smaller, since they have large internal markets (Garrett 2000). At the same time, these large OECD markets, and especially the EU and the US, have access to a number of instruments useful for exerting a great deal of leverage over their trading partners. (1) Through their sheer market power they can credibly threaten smaller states with exclusion if they do not compromise on matters of concern to them. At the end of the Uruguay Round, the EU and the US indeed called for the Uruguay Round agreements to be considered a 
'Single Undertaking', and they formally withdrew from the GATT 1947 in order to force other states to follow suit and become full members of the WTO (Steinberg 2002; Gruber 2000). Smaller states therefore had no choice but to approve all the Uruguay Round agreements, including contentious ones such as the agreements on trade in services and on intellectual property rights. (2) The WTO secretariat has no right of initiative similar to that of the European Commission. This gives states with the greatest market power the role of agenda-setters in the international trading system (Scharpf 1999; Steinberg 2002). (3) These same large markets can provide sidepayments to developing countries to get them on board. The agreements on trade in services and intellectual property indeed offered counterbalanced promises of market access for agricultural and textile goods from developing countries. Despite these three mechanisms through which large markets can determine the course of the WTO, judicialisation is likely to remain a necessary condition for positive integration. Several attempts to come to binding obligations in the Tokyo Round failed, and these 'obligations' were watered down to 'codes', not even binding on all members. This was at a time when GATT did not yet have a credibly binding enforcement system. The 'rule of law' ensured by the WTO dispute settlement system consequently has ambiguous effects. Certainly, most legal specialists have observed that the rule of the strongest no longer prevails in the WTO (Hudec 2000; Jackson 1999; Petersmann 1997). But it seems that, after judicialisation, the law of the strongest rules the international trading system.

\section{Alternative hypotheses}

The formulation of possible alternative explanatory hypotheses enhances the falsifiability of the two central hypotheses. (1) In contrast to the hypothesised effect, judicialisation in international trade governance might create a deterrent effect for further integration, both negative and positive. Deal making might become harder, because the commitments may become more salient and compromises more elusive. The tight coupling of decision-making and implementation might make it less likely for decisions to be made in the negotiating arm of the WTO. In accord with this perspective, loose compliance would be a pre-condition for international co-operation. (2) In the same vein, positive integration might produce futile policy effects, whereas other modes of governance would be far better able to produce significant effects (Vogel 1995). (3) Similarly, political actors might seek to avoid integration through legislation, because the political transaction costs are too high (Héritier 2002). They might therefore seek more flexible modes of governance, aimed more directly at the target groups, and by-pass the legislative arm of the WTO, which has to work under conditions of unanimity.

\section{How to go about it}

\subsection{Specifying dependent and independent variables}

The above reasoning can be systematised as follows. The independent variable consists of the absence of judicialisation during the GATT era and the presence thereof since the Uruguay Round, 
along with the creation of the WTO. On the side of the dependent variable, analysis needs to focus on whether and to what extent some WTO commitments constitute positive integration obligations. This undertaking focuses only on policy outputs. In order to investigate the degree to which the existing positive integration agreements have had an impact on the policy of member states, the focus needs to be on both outputs and policy outcomes. The method used for this empirical test therefore consists of process tracing. Table 2 summarises the variation on the independent and the dependent variable.

\begin{tabular}{|l|l|l|}
\hline & Independent variable & Dependent variable \\
\hline \multirow{3}{*}{ Variation } & Absence of judicialisation: GATT 1947 & $\begin{array}{l}\text { - Negative integration } \\
\text { - Failure to achieve positive integration }\end{array}$ \\
\cline { 2 - 3 } & Presence of judicialisation: WTO 1995 & $\begin{array}{l}\text { - Continued negative integration } \\
\text { - Presence of positive integration }\end{array}$ \\
\hline
\end{tabular}

Table 2: Dependent and independent variables

\subsection{Operationalising central concepts}

The independent variable - judicialisation - is operationalised in a quite straightforward manner. Judicialisation is deemed to be present if international rules are subject to binding third party dispute settlement. In the WTO, this has been the case since the old GATT dispute settlement mechanism was reformed in 1989 (GATT 1990). This reform eliminated veto points that had previously crippled its effectiveness for rule enforcement. Since then, it is no longer possible to block either the establishment of a panel, or the approval of the panel's findings, and GATT contracting parties have been able to multilaterally authorise retaliation against non-complying states. In 1994, by creating the WTO Appellate Body, the agreement establishing the WTO added yet another institutional reinforcement to the system - namely, an appeals procedure. This 'appeals court' issues definitive and binding rulings on member states' compliance records. A second indication of judicialisation consists of private parties' access to domestic courts for the purpose of enforcing international rules on the domestic level. In the universe of cases under consideration, this applies in part to the WTO Agreement on Trade-Related Aspects of Intellectual Property Rights (TRIPs), but the WTO Agreement on Government Procurement, which is not binding on all WTO member states, also contains such obligations. The extent to which judicialisation has made WTO commitments more credible can be estimated by comparing the leverage for flouting GATT agreements to the leverage member states have under the WTO system. Although neither the WTO secretariat nor the member states have such systematic data, a qualitative analysis of the way the enforcement system works can show the plausibility of this claim. I therefore deliberately do not adopt a broad or thick concept of judicialisation, which could also be meant to include the evolutionary character of law in adjudicatory systems, the establishment of a normative set of rules, and the interactive effects between adjudication and future rule-making, so eminently present in contemporary international trade relations. The gradual development of a normative system 
of world trade law with its own interpretative authority in the form of the WTO Appellate Body would especially seem to be one of the more profound characteristics of the World Trade Organization. Yet, expanding the definition of judicialisation to include such developments would not only severely strain the amenability of applying causal tools of analysis (since the independent variable would become to fuzzy), it would also require that the analysis be based on a hitherto elusive consensus about the extent to which international trade relations have become norm driven.

The dependent variable - positive integration - will be deemed to exist if two conditions are fulfilled. First, the agreements should contain clear prescriptions that hold for all parties at the negotiating table and that entail market-correcting measures. These can be obligations to introduce product-related or production-related regulation. Second, the agreements should contain an obligation to introduce domestic institutional reforms. Indicators of such new institutions at the domestic level can be new administrative units, the installation or appointment of official recognition and accreditation bodies, the creation of assessment authorities and standardisation agencies, the installation of courts to enforce new rights, and so on.

\subsection{Case selection: hypothesis testing and hypothesis generation}

The units of analysis are specific issue areas in which either positive integration has been achieved or political actors have attempted but failed to introduce binding obligations on the international level. I propose to investigate a total of 7 cases. Here I will devote more in-depth attention to the case that seems most likely to conform to the above hypotheses, i.e. the TRIPs agreement. Four cases are positive integration agreements in the WTO: namely the agreements on intellectual property, health, technical barriers to trade, and investment. These are cases where a test of the central hypotheses is to be conducted in future research. Did political actors motivate their decision to situate new international regulation in the WTO rather than in other institutional contexts of specialised UN agencies because they were seeking to guarantee a strong enforcement mechanism? Three cases are areas in which the political attempt to bring international rules under the jurisdiction of the WTO have been unsuccessful so far, although they are currently under consideration: environment, core labour standards, and competition rules. Here the aim is not to test hypotheses about why they failed, but rather to generate them, i.e. hypotheses are sketched out about why political actors opposing positive integration in these three policy fields have so far successfully prevented their inclusion in the WTO. Methodologically, and with regard to the successful cases of positive integration, I therefore select on the dependent variable, a strategy often thought to lead to biased research results. Under some circumstances, however, this makes it possible to tease out unknown causal mechanisms that underlie the phenomenon under study (Rogowski 1995). This is the case when one wishes to tackle phenomena that well-established and empirically tested theories and conventional wisdom tend to view as anomalous. These imply that positive integration is very unlikely on the international level, let alone on the global level, given the constraints of intergovernmental decision-making (Scharpf 1996 \& 1999). The strategy of 
selecting cases that are least likely in the face of the existing theory, and most likely in the face of the newly developed hypotheses, aims at developing plausible conjectures and identifying hitherto unknown causal mechanisms in casu in the dynamics of international trade relations.

\subsubsection{Four cases of positive integration in the WTO}

So far, four positive integration agreements have been concluded at the WTO. They concern (1) common standards on the domestic protection of intellectual property rights, (2) minimum health standards for imports and exports, (3) rules on the assessment of technical barriers to trade, and (4) rules related to investment.

\begin{tabular}{|l|l|}
\hline Policy field & WTO Agreements \\
\hline $\begin{array}{l}\text { 1. Intellectual property rights } \\
\text { protection }\end{array}$ & $\begin{array}{l}\text { 1. Agreement on Trade-Related Aspects of Intellectual Property } \\
\text { Rights (TRIPs) }\end{array}$ \\
\hline 2. Health & $\begin{array}{l}\text { 2. Agreement on the Application of Sanitary and Phytosanitary } \\
\text { Measures (SPS) }\end{array}$ \\
\hline 3. Technical standards & 3. Agreement on Technical Barriers to Trade (TBT) \\
\hline 4. Investment & 4. Agreement on Trade-Related Investment Measures (TRIMs) \\
\hline
\end{tabular}

Table 3: Positive integration agreements under the WTO

\subsubsection{The agreement on intellectual property rights: The most likely case}

Among these, the WTO Agreement on Trade-Related Aspects of Intellectual Property Rights (TRIPs) displays a remarkable set of characteristics, which makes it particularly amenable to study (Abbott and Gerber 1997; Govaere and Demaret 2001; WIPO 1995; Cottier \& Mavroidis 2002; Beier \& Schricker 1996). This agreement imposes the obligation on all WTO member states to create domestic intellectual property rights legislation and to install institutions that can enforce those rights. Redefining property rights in the domestic economy in this way therefore leads to considerable reform pressure, especially in those countries with only scanty or no protection of intellectual property. Moreover, through the obligation to create domestic courts for the enforcement of intellectual property rights, the agreement indirectly confers rights on individuals and/or firms. In conformity with the theoretical hypotheses of this paper, the TRIPs agreement was reached under the WTO in order to make its commitments more credible. The agreement was not reached under the auspices of the World Intellectual Property Organisation (WIPO), which lacks a credible enforcement system, but was made an essential component of the package of the Uruguay Round agreements that established the WTO. Intellectual property rights holders from industrialised knowledge-intensive countries perceived free trade in non-licensed products as a source of lost 
revenue and exerted political pressure on their governments to make amends for that at the international level. Governments reacted accordingly and designed an international treaty that has been described as an 'exercise in global regulatory coercion' (Govaere and Demaret 2001). From the perspective of intellectual property rights holders, the agreement binding every WTO member to grant domestic intellectual property rights is considered a correction to the negative externality of foregone revenue from patented or trademarked products. Because of these properties, and in the light of the hypothesis postulated here, the TRIPs case is the most likely case. By contrast, in light of hitherto established explanations about the conditions of international cooperation, it is viewed as one of the least likely (Eckstein 1975).

\subsubsection{The agreements on technical barriers to trade, health, and investment}

If the TRIPs agreement can methodologically be treated as the most likely case, the three other instances of putative positive integration should function as the real test to the argument. These comparative control cases are far less of a positive integration burden, but they contain elements of positive obligations or can end up amounting to positive obligations (the following observations largely draw on Hoekman and Kostecki 2001).

The WTO agreement on Technical Barriers to Trade (TBT) indeed primarily seeks to reduce the discriminatory trade effects of domestic standards, and it would therefore only seem to be a case of negative integration. The agreement, however, stipulates that, if standards are used, these should be in conformity with international standards such as those of the International Standards Organisation (ISO). Indirectly, this emergent global set of rules is therefore being brought under the jurisdiction of the WTO. Yet, the choice not to elevate the WTO to the locus of standard setting, but rather to rely on other relevant, specialised agencies, illustrates the imbalance between the strong judicialisation and the weak rule-making arm of the WTO. Furthermore, the ISO is not strictly an intergovernmental organisation, but one granting ample co-decision powers to private parties.

The WTO agreement on the Application of Sanitary and Phytosanitary Measures (SPS) displays similar characteristics. Under this agreement, states are under no obligations to adopt such rules to protect health. Yet, if they do, these rules should be in conformity with international minimum standards, guidelines or recommendations, like those of the Food and Agriculture Organisation (FAO). They should also be based on 'scientific evidence': this confronts panels and Appellate Body members with some tough choices on the weight to attribute to self-declared independent scientific knowledge (or its absence). The SPS agreement also requires common standards for the recognition of conformity assessment procedures. These introduce institutional requirements and the obligation to install an appeals procedure.

The WTO agreement on Trade-Related Investment Measures (TRIMs) is in essence a list of prohibited measures: This would seem to make it a negative integration agreement only. Yet, the elimination of these measures puts some developing countries under considerable reform pressure, since these measueres include rules on local content, trade balancing, foreign exchange balancing 
and domestic sales requirements. Since the TRIMs case constitutes a borderline case between negative and positive integration, interesting insights about the exact nature of the regulation that is being introduced into the field of investment might be gained from the proposed general research perspective.

\subsubsection{Three cases without positive integration in the WTO}

Soon after the conclusion of the Uruguay Round that established the WTO and introduced new areas of public policy under its jurisdiction, political actors started to advocate the inclusion of other positive integration issues in the WTO. Non-governmental organisations (NGOs), politicians, and experts from OECD countries started to advocate the inclusion of international environmental law, core labour standards, or human rights in the WTO legal framework (Petersmann 2001). Since these existing international rules are not part of the 'covered' agreements, thus far this body of international law has remained outside the scope of WTO law, and it is thus subject to other, supposedly weaker enforcement mechanisms. Advanced industrialised countries often include minimum environmental and labour standards in bilateral agreements that offer preferential market access that extends beyond WTO commitments. Developing countries are wary of the internationally binding multilateralisation of such minimum standards. By contrast, those opposing the integration of competition policy into the WTO include US regulators, possibly since the domestic enforcement of competition rules in the US predominantly lies in the hands of domestic courts. This may have led political actors to prefer modes of governance with weak enforcement powers such as the OECD and the International Competition Network (Damro 2004). As market correcting measures, environment, labour, and competition policy constitute positive integration, but in the European case, these have only proven successful when they have been able to rely on domestic courts, not just international third party enforcement.

\section{Conclusion}

In the present paper, I have lent plausibility to the proposition that judicialisation is a necessary condition for the emergence of positive integration in the World Trade Organization. The WTO has indeed been the institutional locus for a set of remarkable agreements, which have remained elusive in the context of other and more specialised UN agencies such as the World Intellectual Property Organization, or which have now bound rules previously agreed upon in the World Health Organization, the International Standards Organization, or in the context of bilateral agreements on investment. As the enforcement arm of the WTO has been strengthened, agreements subject to its jurisdiction have grown more credible, since the likelihood of non-compliance has decreased. This enhanced credibility of WTO commitments has increasingly led political actors supportive of international regulation in a particular non-trade policy field to try and conclude these in the institutional context of the WTO, rather than in separate agreements or international organisations. 


\section{Selected bibliography}

Abbott Frederick M. and David J. Gerber (1997), Public Policy and Global Technological Integration, London, The Hague, Boston: Kluwer Law International.

Abboth, Kenneth W., Robert O. Keohane, Andrew Moravcsik, Anne-Marie Slaughter, Duncan Snidal (2000), 'The Concept of Legalization', International Organization 54 (3): 401-419.

Alter, Karen (1998), 'Who Are the Masters of the Treaty? European Governments and the European Court of Justice’, International Organization 52 (1): 121-147.

Beier, Friedrich-Karl and Gerhard Schricker (Eds.) (1996), From GATT to TRIPs. The Agreement on Trade-Related Aspects of Intellectual Property Rights, IIC Studies, Max Planck Institute for Foreign and International Patent, Copyright and Competition Law, Weinheim: VCH Verlagsgesellschaft.

Bogdandy, Armin von (2001), 'Law and politics in the WTO - Strategies to Cope with a Deficient Relationship’, in: Jochen A. Frowein and Rüdiger Wolfrum (Eds), Max Planck Yearbook of United Nations Law, (Vol. 5), the Hague: Kluwer Law International.

Burley, Anne-Marie and Walter Mattli (1993), 'Europe before the Court: A Political Theory of Legal Integration', International Organization 47 (1): 41-76.

Charnovitz, Steve (2002), Trade Law and Global Governance, London: Cameron May.

Cottier, Thomas and Petros C. Mavroidis (2002), Intellectual property: trade, competition, and sustainable development, Ann Arbor: University of Michigan Press.

Damro, Chad (2004), 'Multilateral Competition Policy and Transatlantic Compromise', European Foreign Affairs Review 9 (2): 269-287.

De Bièvre, Dirk (2002), 'Re-designing the Virtuous Circle: Two Proposals for WTO Reform. An Essay on Resolving and Preventing US-EU, and Other Trade Disputes', in: Journal of World Trade 36 (5): 1005-1013 (revised version of a prize winning essay in the BP/EUI Transatlantic Essay Contest, San Domenico di Fiesole, May 2001).

De Bièvre, Dirk (2003), International Institutions and Domestic Coalitions: The Differential Effects of Negotiations and Judicialisation in European Trade Policy, EUI Working Paper SPS No. 2003/17, San Domenico di Fiesole: Department of Social and Political Sciences, European University Institute.

De Bièvre, Dirk and Andreas Dür (2004), Delegation and Control in European and American Trade Policy, paper at the ECPR Joint Sessions of Workshops, Uppsala, April 2004.

Denzin, N.K. (1978), Sociological Methods, New York: McGraw-Hill. 
Eckstein, Harry (1975), 'Case Study and theory in political science', in: Fred Greenstein and Nelson Polsby (ed), Strategies of Inquiry, London, Amsterdam: Addison-Wesley Publishing Company.

Garrett, Geoffrey (2000), 'The Causes of Globalisation', in: Comparative Political Studies 33 (6/7): 941-991.

GATT (1990), 'Improvements to the GATT Dispute Settlement Rules and Procedures, Decision of 12 April 1989 (L/6489)', in: The Contracting Parties to the GATT, Basic Instruments and Selected Documents, Thirty-sixth Supplement. Protocols, Decisions, Reports 1988-1989 and Forty-fifth Session. Geneva: General Agreement on Tariffs and Trade (July): 61-67.

Gilligan, Michael J. (1997), Empowering Exporters: Reciprocity, Delegation, and Collective Action in American Trade Policy, Ann Arbor: University of Michigan Press.

Goode, Walter (1998), Dictionary of Trade Policy Terms, second edition, Centre for International Economic Studies, University of Adelaide.

Govaere, Inge and Paul Demaret (2001), 'The TRIPs Agreement: A Response to Global Regulatory Competition or an Exercise in Global Regulatory Coercion?' in: Daniel C. Esty and Damien Geradin, Regulatory Competition and Economic Integration, Oxford: Oxford University Press.

Gruber, Lloyd (2000), Ruling the world: power politics and the rise of supranational institutions, Princeton: Princeton University Press.

Héritier, Adrienne (2002), New Modes of Governance in Europe: Policy-Making without Legislating? in Adrienne Héritier (ed.), Common Goods: Reinventing European and International Governance, Lanham: Rowman \& Littlefield Publishers.

Hoekman, Bernard M. and Michel M. Kostecki (2001), The political economy of the world trading system, Second edition, Oxford: Oxford University Press.

Howse, Robert and Kalypso Nicolaidis (2003), Enhancing WTO legitimacy: Constitutionalization or global subsidiarity? in: Governance 16, 1, 73-94.

Hudec, Robert E. (2000), Essays on the nature of international trade law, London: Cameron May

Jackson John H. (1999), The World Trade Organisation: Constitution and Jurisprudence, London: Pinter.

Keohane, Robert O., Andrew Moravcsik, Anne-Marie Slaughter (2000), 'Legalized Dispute Resolution: Interstate and Transnational’, in: International Organization 54 (3): 401-419. 
Keohane, Robert O. and Joseph Nye (2001), Between Centralization and Fragmentation: The Club Model of Multilateral Cooperation and Problems of Democratic Legitimacy, Research Working Paper 01-004, JFK School of Government, Harvard University.

King, Gary, Robert O. Keohane, and Sidney Verba (1994), Designing social inquiry: scientific inference in qualitative research, Princeton: Princeton Univ. Press.

List, Martin and Bernhard Zangl (2003), Verrechtlichung internationaler Politik. In: Günther Hellmann, Klaus Dieter Wolf, and Michael Zürn, (Eds.) Die neuen Internationalen Beziehungen. Forschungsstand und Perspektiven in Deutschland, Baden-Baden: Nomos.

Lowi, Theodore J. (1964), American business, public policy, case-studies and political theory, in: World Politics 16 (4): 677-715.

Mattli, Walter (2001), 'Private Justice in a Global Economy', in: International Organization 55 (4): 919-947.

Mavroidis, Petros C., Thomas Cottier, William J. Davey, Eleanor M. Fox, Gary N. Horlick, Norio Komuro, Douglas E. Rosenthal (1998), 'Is the WTO dispute settlement mechanism responsive to the needs of the traders? Would a system of direct action by private parties yield better results?' Journal of World Trade 32 (2): 147-165.

Mavroidis, Petros C. and Bernard M. Hoekman (1999), Enforcing multilateral commitments: dispute settlement and developing countries, World Bank Working Paper, Washington DC: World Bank.

Mavroidis, Petros C., Hakan Nordstrom, Henrik Horn (1999), Is the use of the WTO dispute settlement system biased? CEPR discussion paper No. 2340, London: Centre for Economic Policy Research.

Messerlin, Patrick (1995), La nouvelle Organisation Mondiale du Commerce, Paris : Dunod.

Messerlin, Patrick (2001), Measuring the Costs of Protection in Europe: European commercial policy in the 2000s, Washington DC, Institute of International Economics.

Palmeter, David and Petros C. Mavroidis (1999), Dispute settlement in the World Trade Organization: practice and procedure, The Hague and Boston: Kluwer Law International.

Petersmann, Ernst-Ulrich (Ed.) (1997), International Trade Law and the GATT/WTO Dispute Settlement System, London, The Hague, Boston: Kluwer Law International.

Petersmann, Ernst-Ulrich (1997b), The GATT/WTO dispute settlement system: international law, international organizations and dispute settlement, London, The Hague, Boston: Kluwer Law International. 
Petersmann, Ernst-Ulrich (2001), Time for integrating human rights into the law of worldwide organizations: lessons from European Integration Law for Global Integration Law, Cambridge: Harvard Law School Working Paper.

Popper, Sir Karl R. (1965), The Logic of Scientific Discovery, London: Hutchinson \& Co.

Risse, Thomas (2001), 'Transnational Actors and World Politics', in: Walter Carlsnaes, Thomas Risse and Beth A. Simmons, Handbook of International Relations, London: Sage.

Risse, Thomas, Kathryn Sikkink and Stephen C. Ropp (Ed) (1999), The Power of Human Rights. International Norms and Domestic Change, Cambridge: Cambridge University Press.

Rittberger, Volker, Andreas Hasenclever and Peter Mayer (1997), Theories of International Regimes, Cambridge: Cambridge University Press.

Rogowski, Ronald (1989), Commerce and Coalitions: How Trade Affects Domestic Political Alignments, Princeton: Princeton University Press.

Rogowski, Ronald (1995), 'The Role of Theory and Anomaly in Social-Scientific Inference', American Political Science Review 89 (1): 7-10.

Ruggie, John G. (1982), "International Regimes, Transactions, and Change: Embedded Liberalism in the Postwar Economic Order", International Organization 36, 2, 379-415.

Scharpf, Fritz W. (1996), 'Negative and Positive Integration in the Political Economy of European Wellfare States', in: Gary Marks, Fritz W. Scharpf, Philippe C. Schmitter, Wolfgang Streeck, Governance in the European Union, London: Sage.

Scharpf, Fritz W. (1999), Governing in Europe: Effective and Democratic? Oxford: Oxford University Press.

Scharpf, Fritz W. (1988), 'The Joint Decision Trap: Lessons from German Federalism and European Integration', Public Administration 66: 239-278.

Steinberg, Richard (2002), 'In the Shadow of Law or Power? Consensus-Based Bargaining and Outcomes in the GATT/WTO’, International Organization 56 (2): 339-374.

Stone Sweet, Alec (1999), 'Judicialization and the Construction of Governance', Comparative Political Studies 32 (2): 147-184.

Stone Sweet, Alec and Thomas Brunell (1998), 'Constructing a Supranational Constitution: Dispute Resolution and Governance in the European Community', American Political Science Review 92: 63-81.

Tinbergen, Jan (1954), International Economic Integration, Amsterdam: North Holland. 
Trebilcock, Michael J. and Robert Howse (1999), The Regulation of International Trade, $2^{\text {nd }}$ edition, London and New York: Routledge.

Vanberg, Viktor (1992), 'A constitutional political economy perspective on international trade', Ordo 43: 375-392.

Verdier, Daniel (1994), Democracy and International Trade: Britain, France and the United States, 186-1990, Princeton: Princeton University Press.

Vogel, David (1995), Trading Up: Consumer and Environmental Regulation in a Global Economy, Cambridge, MA: Harvard University Press.

Weiler, Joseph H.H. (1991), ‘The Transformation of Europe’, Yale Law Journal 100: 2403-83.

Weiler, Joseph (1994), 'A Quiet Revolution: The European Court of Justice and its Interlocutors', Comparative Political Studies 26 (4): 510-534.

Weiler, Joseph H.H. (2000), The Rule of Lawyers and the Ethos of Diplomats: Reflections on the Internal and External Legitimacy of WTO Dispute Settlement, Harvard Jean Monnet Working Paper 09/00, Cambridge, MA: Harvard Law School.

World Intellectual Property Organization (WIPO) (1997), Introduction to Intellectual Property: Theory and Practice, London, The Hague,Boston: Kluwer Law International.

World Trade Organization (WTO) (1995), The Legal Texts. The Results of the Uruguay Round of Multilateral Trade Negotiations, Cambridge: Cambridge University Press.

Zürn, Michael (2000), 'Democratic Governance Beyond the Nation State: The EU and other International Institutions’, European Journal of International Relations, 6 (2): 183-221. 